\title{
Authorizing Indonesian Diversity through the Inheritance of Multiculturalism Values Based on Local Wisdom of Maluku People
}

\author{
Agustinus Ufie \\ History Education Department \\ Pattimura University \\ Ambon, Indonesia \\ ufieagust@yahoo.co.id
}

\begin{abstract}
The reality of Indonesia diversity as a nation, today, enters momentum which is very worrying. Various social phenomena in society such as violence, conflict, terrorism, up to the chaotic of national politic (sectarian politic), etc. continually occur in the midst of our national life. These empirical facts show that spirit of pluralism as the power, which binds us, begins to fragile. Whereas diversity is a foundation for presenting a pluralistic Indonesia is slowly faded away. We begin to lose our foothold. Those phenomena should not be continually abandoned. Various efforts should be done to minimize or even stop all phenomena which threat our diversity. Improving nationality character and the spirit of diversity by continually inherit multiculturalism values from various local wisdom are powers to unite us are the important and urgent things to do. Therefore, this study is focused on the manifestation of multicultural values which are derived from the local wisdom which grow and develop in the midst of community life. The local wisdom of Maluku People is the identity of Maluku community which is full of social, moral and ethical values which bind its community continuously. Manifesting local wisdom values in social relation to its community continuously is one way to confirm Indonesia diversity. Therefore, the social harmony is maintained continuously for the sake of the united, secure and peaceful Indonesia.
\end{abstract}

Keywords - diversity, multiculturalism, local wisdom and social harmony

\section{INTRODUCTION}

Indonesia is one of the widest archipelago countries in the world and has various diversity in terms of natural sources, human resources, and socio-cultural. The empirical fact of this diversity had made Indonesia as a pluralistic nation-state as well as world mosaic. It is in accordance with as expressed by Yaqin [1] that Indonesia has a socio-cultural or geographical diversity in which geographically Indonesia consists of 13.667 islands which are inhibited or not inhibited and consist of 358 tribes and 200 sub-tribes of its nation, and certainly have various local cultures which are different from one another. This reality concerns many people whether this diversity can realize a nation unity. This concern has expressed by Robert Cribb [2] who views that the map is enough to give an impression that it is impossible that Indonesia country exists. However, the doubt from the perspective that unity as a sovereign country is not proved because The Unitarian State of the Republic of Indonesia up to now still firmly stand out, stretched from Sabang to Merauke and inhabited by various tribes who have one region, culture, and tradition accompanying the journey of The Indonesia.

The diversity, which has strengthened the Unitarian State of The Republic of Indonesia, should be able to be managed to become a power in order to present harmony, peace, unity, and not vice versa. Susanto Zuhdi [2] expressed that the problem faced today is in nations' unity context and unitary state is how to appreciate diversity as a necessity for Indonesia which is free, united, sovereign, and prosperous. The spirit of nations' unity over the diversity also is expressed by Hamid Hasan [3] that cultural diversity in one side is a nation's wealth, but on the other side, it can become detrimental conflict source. If it refers to the authentic fact, the diversity in Indonesia from the socio-cultural perspective (culture, tradition, language, tribe, race, and religion) must become strength, but it can be a weakness if we are unable to manage the diversity well.

Diversity is an identity of Indonesia and also the power to build nation civilization because actually diversity is an incredible cultural base in the life of Indonesian, as what is believed by State Secretariat Minister Pratikno, in Carnival of Cultures when commemorating the $72^{\text {nd }}$ Indonesian Independence Day in Bandung, stated that Indonesia has an incredible cultural base. This cultural base becomes an asset for our society. It can be used to build a social power; one of them is by strengthening tolerance among citizens (Kompas, $27^{\text {th }}$ August 2017). Therefore, those cultures should be continuously preserved from one generation to the next generation through various ways. Those cultures and traditions have social, moral, and ethics values which are upheld and had inspired, guided, and guarded various life activities of the local community as local wisdom. It becomes necessary and urgent to raise people's awareness that social relation should be continuously building due to culture and tradition's demand in the midst of society. It is done because social relation will manifest social harmony and it can strengthen tolerance toward difference, and finally toward the spirit of unity, civilized humanity in our life as a pluralistic nation. However, if that awareness is not realized or 
manifested, it will hard to achieve social harmony and every day we will see conflict and violence.

Today, with open eyes we will witness social harmony which is increasingly reduced. Various conflicts on tribal, religious and racial nuance, violence, radicalism and terrorism, and also political identity had found their way. These situations indicate that the spirit of unity and brotherhood in Indonesia begin to fade away. The chaos in our nation raises a big question on what is actually wrong in our togetherness as a nation. Whether or not the diversity as a power in uniting us in a nation had been degraded, it results in conflict and violence. In order to avoid conflict which is resulted by social disharmony, then we must be able to find the right way as a solution to minimize and even eliminate all forms of conflict.

Promoting and preserving cultural values which grow and develop in a community as local wisdom is the way to reduce or even resolve those various conflicts. As asserted by Nasaruddin Umar, The Indonesia Vice Minister of Religious Affair in National Seminar on Religion and Pluralism in Maluku in 2011, stated that local wisdom which grows in various regions can be utilized to reduce and eliminate conflict because Indonesia prefers the cultural approach in solving various matters [4].

Therefore, this paper aims to trace various local cultures as local wisdom in Maluku community. Because these traditions are full of social, moral, and ethic values and it is evident that they guide, direct, and guard community in building the living among them who have the difference in social status, tribe, and religion. The local wisdom which continuously grows and develops in various regions in Maluku had become community's identity and also a manifestation of cultural diversity in Indonesia. According to Gobyah [5], local wisdom is the truth which has become a tradition in a region. Therefore, tribal, racial, religious, and linguistic diversity in Indonesia should be ordered well because actually diversity is power as well as conflict source.

Maluku is one region in Unitary State of the Republic of Indonesia which is inhabited by various tribes with its various local traditions which always dynamical along with its community development. Maluku can be said as Indonesia miniature because each region in Maluku has culture, tradition, and its own local language, and they can be grouped in six clusters of culture; Namlea Buru (Bupolo), Seram (Nusa Ina), Ambon Lease, Southeast (Kei), Southeast (Tanimbar) and Southeast (Southwest). This paper aims to explore three local cultures of the community who lives in Southeast Peninsula of Maluku Islands namely Ain Ni Ain culture in Kei Islands, Fangea Kidabela culture in Tanimbar Island, and Kalwedo culture in Maluku Westeast community in the outermost region of Indonesia. Those cultures contain social and moral values and become life guidance for their community. This local wisdom should be continuously cultivated in various ways in order to strengthen the identity of its community in the midst of modern culture attack. Promoting and inheriting local wisdom values through various approaches (learning in school, cultural festival/carnival, and establishing cultural centers) are good ways to reconfirm the diversity and to strengthen the community's identity in the midst of modern culture attack.

\section{THEORYTICAL StUdy}

\section{A. Local Wisdom as an Identity of Local Community}

Various cultures and traditions in the life of local community had become the community's need because those cultures had become a philosophy, attitude, and creativity of its community which had been existed along with humans' existence. It is in accordance with Saini KM [6] who expressed that local wisdom is attitude, philosophy, and capacity of its community in managing its mental and physical environment, and which gives the ability to grow and survive in the region where they live. In the other word, local wisdom is a creative answer to the geographical-geopolitical and historical situation in that community. Furthermore, Mutakin [7] defined local wisdom as:

The individual or group of people's capacity to think, feel, show attitude, and act in the effort to introduce and inculcate idea, concept, expectation, suggestion or some information relate to values and norms as reference of how to live and how to live is developed and enjoyed as it should be, so it becomes meaningful and beneficial for that individual and his environment.

Meanwhile, Sutarto [8] mentioned that local wisdom (tradition) which is used as guidance in social life is a central part of a tradition. Tradition is a habit passed from one generation to the next generation which reflects the existence of its followers.

Therefore, introducing and continuously preserving the lofty values of local wisdom to young generation become a necessity in order to maintain nation's diversity, so it can create social harmony everywhere. Since local cultural values had become the soul of local culture as national cultural wealth, social disharmony of a community in national society can be avoided.

\section{B. The Essence of Value}

The definition of value as written in Great Dictionary of Indonesian Language (1990) is worth, something important and useful for humanity. The word value explains the good and the bad of something done by humans (society) both personally and in a group. Therefore, Fraenkel [9] defined value as a standard of behavior, beauty, justice, truth, and efficiency which ties humans and should be practiced and maintained. Value has the essence attached to something very meaningful for human life. The value in cultural perspective is something very important because it becomes criteria, foundation, and motivation for cultural believers in interacting with one another. In accordance with it Budiyono [10] who expressed that value is a quality of something useful for human life both physically and mentally. In human life, a value is made to become foundation, rational or motivation in behaving. A value is material and immaterial. Immaterial value is not concrete or cannot be perceived by five senses but can be felt. The more concrete form of immaterial value 
concept in social life is what is known as a norm of social life. Meanwhile, the value according to Kusumohadidjojo (2009) is a degree, a quality which makes something is preferred, desired, useful or become an object of interest. The concept of values according to Halstead \& Taylor [11] is basic principles and belief which guide and direct behavior; the standard/criteria of good or bad for something done. Therefore, a value is something important, high valued, should be applied, should be achieved or at least is inspired [4].

\section{Multiculturalism and Diversity}

Essentially, multiculturalism expresses two important things which should be announced by everyone, namely difference, and respect. If we understand multiculturalism in deeper then actually the existing differences are our power to continuously develop because we have respected diversity in cultures, languages, tribes, and religions. This also asserted by Tillar [12] who stated that multiculturalism is the institutionalization of cultural diversity-owned by ethnical groups in a nation-state through language, legal systems, governmental policies in health and housing, education, and another field. It means that multiculturalism is a principle which believes that difference and diversity in a culture have a value of togetherness. Diversity and difference are power. In social-political life, diversity and difference are expressed through democracy because democracy is actually a soul which guarantees multiculturalism culture. Meanwhile, Suparlan [13] mentioned that in multiculturalism, society has a culture which is generally applied because society is like a mosaic. The mosaic includes all cultures from the smaller society to form the bigger society, who has a culture like that mosaic.

Kymlicka [14] more emphasized the essence of multiculturalism. He mentioned that multiculturalism is a respect given by majority ethnic and culture to a minority. The respect of this sharing is a reality which should be managed well in ordering the collective life of a nation. Whereas, Stevenhagen [15] categorized multiculturalism into two principle things, namely (a) multiculturalism as social reality in heterogeneous society, because from this aspect about $90 \%$ countries in the world is essentially multicultural due to its ethnic and cultural plurality; (b) multiculturalism had been promoted as a belief, ideology, attitude, and policy which respect its ethnic and culture pluralism as something valued, potential, and should be maintained and built. In accordance with it, Blum [16] defined multiculturalism as an understanding, respect, and assessment of one's culture and a respect and curiosity toward another ethnic and culture. It comprises an assessment of other cultures, but not in a sense that it agrees on all aspects of those cultures, but tries to see how certain culture can express value for its own members. Kebhinekaan derived from the word bhineka which contains different meaning. Kebhinekaan actually expresses diversity in tribe, race, religion, language, and culture; furthermore, diversity is the main pillar in establishing Indonesia. Since its emergence of independent and sovereign state overall diversity existed in whole clusters of the archipelago, stretched from Sabang to Merauke, it is not hinder the growth of brotherhood spirit as one nation.

\section{DISCUSSION}

\section{A. Promoting Local Wisdom Values to Maintain Social Harmony}

Globalization flow is continuously entering our life. This situation certainly makes competition between local cultural values and modern culture become inevitable. Modernization can destruct all culture orders which had been build thousand years ago. Anthony Giddens [17] expressed that modernization can be defined in two perspectives. In one side, modernization can become the engine which destructs local value and tradition. On the other side, modernization can become a change toward civil social order. Giddens more look at modernization now as uncontrolled "juggernaut" (giant barracuda). The term "juggernaut" used by Giddens to describe modern life as "a runaway world". Modernity more emphasizes on individualism which ignores togetherness, so Doyle Paul Johnson [18] asserted that individualism weakens social ties which unite individual with another social group or with society in general and can make this life becomes socially less meaningful. In the spirit of modernization and modernity, Huntington [19] asserted that "it is true that modernity is tightly related to political stability, on the other hand, modernity is related to instability." Furthermore, Huntington explained that modernity is a goal terminal, whereas modernization is a process toward the last condition of that goal which is full of obstacles.

On another side, I Wayan Ardika [20] argued that both local and national culture systems, which both used as a reference by society experience, change because of the influence of global cultural values, particularly information technology advance is increasingly accelerating the process of that change. Values competition happens because of cultures shift. If we cannot manage the shift from traditional social order into modern social order, it will result in deterioration, ambiguity, dispute, etc. This shift will invoke disharmony, so diversity and unity will become something difficult to be achieved. As the future heirs, we should be able to stand upright and step into modernization without leaving our traditionalism, building collective awareness that the culture which is cultivated in a local community is our identity, inhered to earlier generation to us and we should inherit that to the next generation. Because actually identity is very meaningful, it has values which can live even in the midst of modernity. Those cultural values had become the stick in building social relation among one another. Regarding this, Suhartono Pranoto [21] asserted that:

Before we become modern society, of course, we consider culture as a national heritage which we have felt until now (culture heritage). Why it continues from generation to generation because culture contains some values which are very meaningful for the existence of a nation or an ethnic. The local culture content which is 
the heritage from earlier generation has cultural values which capable to protect another life aspects such as political, social, economic, and religious life.

Continuously accessing various cultures in local community life is one way to confirm self-identity and to strengthen our diversity as a pluralistic nation. It is the nation which was born from socio-cultural and geographical diversity and stretched from Sabang to Merauke.

Maluku is a province. The width of the sea is more than the width of its land. This makes Maluku has its own characteristic that certainly differs from another province in Indonesia, in which the big and small islands are inhabited by various kind of tribes and have various cultures, traditions, and local languages. Despite difference in culture and language, they have the spirit of brotherhood and unity among them as Maluku ethnic. The community who lives in the island in Maluku is not only homogenous union but also has ecological, economic, and social-cultural variety which is also subcultures which have a custom, language, religion, belief and ethical group variety [22]. The manifestation of togetherness and brotherhood spirit as Maluku ethnic is expressed from the life philosophy "potong di kuku rasa di daging". This expression actually reflects the spirit of Maluku people that katong samua orang sodara/bersaudara (we are all brothers). It contains the meaning that if one suffers from trouble, of course, the others will feel that suffer too, similarly if one is happy, of course, the others will feel happy too.

The diversity of culture, language, and tribe even in Maluku continuously developed from time to time in accordance with its community development. This empirical reality can be encountered in the life of each indigenous people who inhabit various small islands or big islands in the cluster of Maluku Islands. The diversity in Maluku Island is very interesting to be traced in the effort to confirm the perspective of our identity as a big nation which was born from diversity content. Therefore, this study will present empirical fact of local wisdom values belongs to indigenous people who live in small islands exactly in Southeast peninsula of Maluku islands, namely Kei Islands, Tanimbar Islands and Southwest Maluku Islands. Each community of indigenous people who live in those islands has local culture and tradition which are very strong and tie them. Those traditions have become guidance in building relation or interaction among them for centuries.

\section{B. “Ain Ni Ain” Cultural Value as The Local Wisdom of Kei People}

Ain Ni Ain culture as the life order of indigenous people in Kei islands is a habit which had become a tradition and has a strong influence in directing, guiding, and guarding all behaviors and attitudes of its believers in building social relationship among them. Ain Ni Ain can be defined as "the feeling of belonging to each other" or the manifestation of brotherhood form (katong semua bersaudara). This life philosophy is actually similar with Bhineka Tunggal Ika (Unity in diversity) [23]. Ain Ni Ain tradition actually is a legacy of the local community which is full of wisdom, social, and moral values and has become local wisdom of the local community. Those values can be described in the table as follow:

TABLE 1. THE DESCRIPTION OF AIN NI AIN CULTURAL VALUE

\begin{tabular}{|c|c|c|}
\hline No & Value & Description \\
\hline 1 & $\begin{array}{l}\text { Hira ni tub fo I ni } \\
\text { /honesty }\end{array}$ & $\begin{array}{l}\text { The attitude of sincere, fair, } \\
\text { generosity to human fellows. } \\
\text { Dare to tell the wrong and the } \\
\text { right. }\end{array}$ \\
\hline 2 & $\begin{array}{l}\text { Hamaren/help each } \\
\text { other }\end{array}$ & $\begin{array}{l}\text { The attitude of mutual help, } \\
\text { help human fellows without } \\
\text { expecting a reward, like to help } \\
\text { in reducing the others' burden } \\
\text { in joy and sorrow with } \\
\text { familiarity. }\end{array}$ \\
\hline 3 & $\begin{array}{l}U b \text { let } u j a / \text { respect } \\
\text { each other }\end{array}$ & $\begin{array}{l}\text { The feeling of respect each } \\
\text { other as one brother. Uphold } \\
\text { difference among human } \\
\text { fellows. }\end{array}$ \\
\hline 4 & Tet $\mathrm{Ya}$ /gratitude & $\begin{array}{l}\text { The attitude of return the favor, } \\
\text { grateful to human fellows. }\end{array}$ \\
\hline
\end{tabular}

Therefore, actually, Ain Ni Ain culture in Kei islands reflects a life pattern or a habit of the community which is invaluable. This good habit should be manifested in the interaction among human fellows, so however strong the influence of modern culture, the people will not leave their tradition. It is important to continuously build community awareness that culture is an identity which is full of social and moral values such as hira ni tub fo $i$ ni/honesty, hamaren/help each other, $U b$ let $u$ jo/respect each other, Tet Ya/grateful. Because these values are very efficient to prevent even stop various social unrest, violence, conflict and also block the negative influence of modernization which enters the life of the community itself. Besides, building people's awareness about the importance of culture is an effort to strengthen the spirit of togetherness as a nation.

\section{C. "Fangea Kidabela" Cultural Value as The Local Wisdom of Tanimbar People}

Fangea Kidabela is one manifestation of the local wisdom in the a community who slive in the cluster of Tanimbar Islands. Fangea kidabela tradition has strengthened relation, tightened the spirit of friendship and brotherhood of Tanimbar Community. Fangea Kidabela contains the meaning of strengthening brotherhood and friendship tie and relation among all people from two villages [24]. Kidabela is friendship or brotherhood relation [25]. Meanwhile, McKinnon [26] described kidabela in Tanimbar as similar as pela in Ambon island. McKinnon described fangea kidabela as follow:

The villages which are built together in the relation of
younger and older brothers' unity are called as yaan
iwarin or simply as kidabela friends. Each village
maintains one brotherhood or friendship unity with one
another from three until ten (or more) other villages,
which are located in the same island, or in other islands,
with very long distance.

The greatness and sanctity of Fangea Kidabela tradition can be seen through the performance of inabar ilaa dance. This 
dance actually shows accumulation of historical value and religious value of the ancestors who had cultivated as social institution of Tanimnar community. Fangea kidabela tradition reflects social and moral values which had become base for the sense of brotherhood and friendship. It can be described in the table below:

TABLE 2. DESCRIPTION OF FANGEA KIDABELA CULTURAL VALUE

\begin{tabular}{|l|l|l|}
\hline No & Value & Description \\
\hline 1 & $\begin{array}{l}\text { This attitude asserts that each } \\
\text { appreciate } \\
\text { human or individual is equal, } \\
\text { so respecting and appreciating } \\
\text { each other is very important in } \\
\text { building interaction among } \\
\text { fellows This attitude can be } \\
\text { implemented by greeting each } \\
\text { other, doing good act, and } \\
\text { sacrificing for each other. }\end{array}$ \\
\hline 2 & $\begin{array}{l}\text { This attitude asserts that } \\
\text { continuously maintaining good } \\
\text { relation among fellows, } \\
\text { prioritizing harmony, treating } \\
\text { each other well and } \\
\text { responsibly, visit each other } \\
\text { Desir/Harmony }\end{array}$ & $\begin{array}{l}\text { (maintain good relation). } \\
\text { rafel }\end{array}$ \\
\hline
\end{tabular}

Fangabea kidabela actually regulates the life of Tanimbar people in how to build their life based on tsialang value namely respect and appreciate each other. Tsialang asserts the attitude of respect each other, younger people respect older people, a community respects their leader and vice versa. Tsialang wants its community to do good act, sacrifice to the others who need help. This attitude should be build in the midst of modernization which threats all aspects of life in world society because actually tsialang was born from fangea kidabela which has strong influence.

Fangea Kidabela want its community to visit each other, because actually it can strengthen good relation and it is here that togetherness, brotherhood, and friendship value will be continuously maintained and long lasting, as such social harmony has found its way. Fangea kidabela also wants each individual to have responsible attitude, the responsible is not only in customary matters, but responsible in all life's aspects relate to cultural and religious matters and in daily life. Therefore, the values contained in Fangea Kidabela culture of Tanimbar people should be maintained and continuously built, and preserved from generation to generation because, actually, local wisdom values are the identity of local community and become the main support of social harmony.

\section{D. "Kalwedo" Culture as The Local Wisdom of Southwest Maluku People}

Kalwedo [22] is the words spoken as the sign of brotherhood which is practiced in the life of indigenous people in Southwest Maluku islands. This culture has become the identity of indigenous people who live in the area of those islands. Those islands are the outermost of Indonesia which bordered with Democratic State of Timur Leste and Australia. Due to the geographic location of those islands, there is worry whether the spirit of nationalism and the spirit to maintain the lofty values of local culture as a manifestation of Indonesia diversity keep existed in the heart of each people who live in the islands in the furthest south of Maluku Island. That worry does not come without reason. The geographic closeness and the genealogy history of community there gives a bit conclusion of that question and worrying is very reasonable.

Therefore, various efforts should be done particularly in the areas of Southwest Maluku. Those efforts actually devoted to strengthening the spirit of Indonesia based on lofty values contained in culture or tradition of local people. Preserving local culture values such as Kalwedo culture in indigenous people in Southwest Maluku islands is the manifestation of our love to Indonesia diversity. Why is it so? Because, actually, Kalwedo culture is the life principles which is made to become a reference in building a civilized and dignified life [22]. Kalwedo contains brotherhood, solidarity, love, mutual help, good relationship (visiting), and sincerity values. If these values continuously grow in the life of the community, social harmony in its community diversity and eternal unity as nation-state is never shaken. Those values can be seen in the table as follow:

\begin{tabular}{|l|l|l|}
\hline TABLE 3. DESCRIPTION OF & KALWEDO CULTURAL VALUE \\
\hline No & Value & Description \\
\hline 1 & Peace/brotherhood & $\begin{array}{l}\text { The attitude in which everyone } \\
\text { is demanded to continuously do } \\
\text { a good act, keep their words so } \\
\text { social harmony will be realized. }\end{array}$ \\
\hline \multirow{2}{*}{ Love and affection } & $\begin{array}{l}\text { The attitude of love each other, } \\
\text { and respect each other as one } \\
\text { family which are continuously } \\
\text { manifested in behavior, } \\
\text { communication, and } \\
\text { interaction. }\end{array}$ \\
\hline Sacrifice & $\begin{array}{l}\text { The attitude of willing to } \\
\text { sacrifice for human fellows } \\
\text { based on the awareness that } \\
\text { everybody is the brother who } \\
\text { should be helped if they need it, } \\
\text { willing to sacrifice for common } \\
\text { interest. }\end{array}$ \\
\hline
\end{tabular}

Those values contained in Kawelda culture had described a power of tradition to regulate, direct and bind all behaviors of indigenous people who live in that area. Those tradition values are the heritage from our ancestors which have strong influence and therefore they should be preserved, so our selfidentity as indigenous people keep maintained even though modernization culture is continuously attacked us. Through this custom process, the trust system among one with another is increasingly strengthened. If the trust grows among them, certainly social unity as one community will be strong. Fukuyama [27] said that giving high value on trust will determine the life of survival of a community. Without trust, everybody will suspect each other and it means the end of a community.

\section{CONCLUSION}

Various local cultures had become the identity of a local community to grow and develop in the midst of indigenous people life in Maluku islands. Local culture grows civilization atmosphere and social regularity which are peaceful and based on lofty values of each culture. Those various local cultures are the expression of identity to represent the conscience of each individual who is joined in the community of indigenous 
people and show the way toward the civilization of its community which is unwavering.

The community of indigenous people which is build based on the spirit of togetherness is an existence which is capable to organize and regulate social unity from various spheres to accept each other, respect each other, help and unite each other, and build social relation which is ordered completely and perfectly. Various cultures which grow and develop can be used to unite all components of society without viewing diversity as an empirical reality. Various cultures and traditions become the main support of our diversity.

Building people's awareness of various cultures which grow and develop as civilization base will give clarity to them about humanization values. Therefore, we all should be aware of how important to maintain local wisdom values in the midst of massive exodus of modern culture in order to strengthen our social relationship as a strong nation-state due to its diversity.

\section{REFERENCES}

[1] M.A. Yaqin, Multicultural Cross-Cultural Understanding Education for Democracy and Justice,Yogyakarta: Pilar Media, 2005.

[2] S. Zuhdi, Maritime Nationalism, and History, Jakarta: Bambu Press Community, 2014.

[3] H. Hasan, Educational History of Indonesia, Issues in Ideas and Learning, Bandung: Rizqi Press, 2012.

[4] U. Agust, "The Inheritance of Local Wisdom Values of Key Society Through The Learning of History As an Effort to Build Social Cohesion," Journal of Scientific Knowledge Window Media Information and Educational Communication, ISSN: 1979-7842. Vol. 6, October 2013

[5] I K. Gobyah, "Based on the Local Wisdom," in http://www.balipos.co.id, accessed September 11, 2011.

[6] K.M. Saini, "Local Wisdom in the Global Era," People's Thought, Issue of July 30, 2005.

[7] M. Laundry, The Values of Cultural Wisdom and Tradition Behind the Symbol (Totem) Brass Horse, Bandung: Universitas Pendidikan Indonesia, 2005.

[8] S. Ayu, Local Wisdom of Java, the Sublime Messages of the Ancestors. Surabaya: Field of PNFI-Value Culture, Education Office of East Java Province, 2010.

[9] J.R Fraenkel, How to Teach Abaout Values, An Analytic Approach New Jersey: Prentice-Hall Inc, 1977.
[10] Budiyono, The Values of Personality and Struggle of Indonesian Nation, Bandung: Alfa Beta, 2007

[11] Halstead and Taylor, "Learning and Teaching about Values: A Review of Recent Research", Cambridge: Journal of Education, Vol. 30, No.2, 2000

[12] H.A.R.Tilaar, Cultural Education and Sivil Society, Bandung: PT Remaja Rosdakaya, 2004

[13] P. Suparlan, "Towards Indonesian Multiculturalism Society, Journal of Indonesian Anthropology, Yayasan Obor Indonesia, Year XXVI, Vol. 69 , p. 02,2002

[14] K.Will, Multicultural Citizenship, Edlina Hafmini Eddin's Translation, Jakarta: LP3ES, 2002.

[15] R.Stavenhagen, The Problems and Prospects of Multiethnic State, Tokyo: United Nations University Press, 1986.

[16] A. Lawrence Blum, Antiracism, Multiculturalism and Inter-Race Community, Three Educative Values for a Multicultural Society, in Larry May and Shari Collins Chobanian, A Multicultural Approach of an Applied Ethics, Translator: Sinta Carolina and Dadang Rusbiantoro: Yogyakarta Tiara discourse, 2001.

[17] A. Giddens, The Consequences of Modernity, Polity Pres Ltd: Cambridge, 2004.

[18] D.P. Johnson, Sociological Theory Classical Founders and Contemporary Perspectives, John Wiley and Sons: Inc. All rights reserved, 1981.

[19] S. P. Huntington, The Change to Change: Modernization, Development, and Politics, Yale University Press, 1971.

[20] I. W. Ardhika, History and Dialogue of Civilization. the 70th years Dedication of Prof. Dr. Taufik Abdullah, Jakart: LIPI Press, 2005.

[21] S. Pranoto, History and Dialogue of Civilization. the 70th years Dedication of Prof. Dr. Taufik Abdullah, Jakarta: LIPI Press, 2005.

[22] A. Watloly, F.Matakena, D.Saiya, and F.Dahaklory, Kalwedo Culture in Southwest Maluku, Ambon: Balai Kelestarian Nilai Budaya, 2012.

[23] A.Ufie, "Integrating Values of Local Wisdom-Based Multiculturalism as a Learning Sources of History," Scientific Journal of CRIKSETRA UNSRI Palembang, ISSN: 1978-8673, Vol. 3, No. 6, November issue, 2014.

[24] A. Batkunde, C. Rumfan, Weridity and B. Anita, The Fangea Kidabela Ceremony of Tanimbar Society, Ambon: Balai Preservation Cultural Values, 2012.

[25] W. Amrosius, The Confraternity of Tanimbar Society Model of Local Wisdom, Yogyakarta: Canisius Publishers, 2012.

[26] S. McKinnon, The Cooless of Peace, the Heat of the Contest: Intervillage Alliance in the Tanimbar Island, Leknas LIPI-Pattimura University - Depdikbud, 1984.

[27] F. Francis, Trust: The Social Virtues and the Creation of Prosperty, New York: Basic Books, 1995. 